\title{
Oxidative Stress and Inflammatory Biomarkers Analysis of Biofield Treated Proprietary Test Formulation in Heart Tissues in Cecal Slurry, LPS and $E$. Coli-induced Systemic Inflammatory Response Syndrome (SIRS) in Sprague Dawley Rats
}

\author{
Mahendra Kumar Trivedi ${ }^{1}$, Alice Branton ${ }^{1}$, Dahryn Trivedi ${ }^{1}$ and Snehasis Jana ${ }^{2 *}$ \\ ${ }^{1}$ Trivedi Global, Inc., Henderson, Nevada, USA \\ ${ }^{2}$ Trivedi Science Research Laboratory Pvt. Ltd., Thane (W), Maharashtra, India
}

Submission: June 21, 2021; Published: July 13, 2021

"Corresponding author: Snehasis Jana, Trivedi Science Research Laboratory Pvt. Ltd., Thane (W), Maharashtra, India

Abstract

The study was aimed to evaluate the antioxidant and anti-inflammatory biomarkers in heart tissues after treatment with the Biofield Energy Treated Proprietary Test Formulation and Biofield Energy Treatment per se to the animals on Cecal Slurry, LPS and E. coli-induced systemic inflammatory response syndrome (SIRS) model in Sprague Dawley rats. In this experiment, different antioxidants biomarkers such as myeloperoxidase (MPO), superoxide dismutase (SOD), lipid peroxidase (LPO) and proinflammatory cytokines such as tumor necrosis factor- $\alpha$ (TNF- $\alpha$ ), interleukin-6 (IL-6), macrophage inflammatory protein-2 (MIP-2), and matrix metallopeptidase 9 (MMP-9) were analysed using ELISA assay in heart homogenate. A proprietary test formulation was formulated including minerals (magnesium, zinc, calcium, selenium, and iron), vitamins (ascorbic acid, pyridoxine $\mathrm{HCl}$, vitamin $\mathrm{E}$, cyanocobalamin, and cholecalciferol), Panax ginseng extract, $\beta$-carotene, and cannabidiol isolate. The constituents of the test formulation were divided into two parts; one section was defined as the untreated test formulation, while the other portion of the test formulation and the animals received Biofield Energy Healing Treatment remotely for about 3 minutes by a renowned Biofield Energy Healer, Mr. Mahendra Kumar Trivedi.

The level of MPO was reduced by $12.07 \%$ in the G6 (Cecal Slurry, LPS and E. coli along with Biofield Energy Treatment per se to animals from day -15) group as compared to the untreated test formulation (G4) group. Moreover, the level of SOD was significantly ( $\leq \leq 0.05)$ increased by $19.03 \%, 17.26 \%$, and $11.81 \%$ in the G6, G7, and G9 groups, respectively as compared to the G4 group. The level of TNF- $\alpha$ was significantly decreased by $25.97 \%, 40.28 \%$ (p $\leq 0.01$ ), $24.86 \%, 36.54 \%$ ( $\mathrm{p} \leq 0.01$ ), and $34.30 \%$ in the G5, G6, G7, G8, and G9 groups, respectively as compared to the disease control (G2) group. Moreover, the level of IL-6 was significantly ( $\mathrm{p} \leq 0.001$ ) decreased by $23.5 \%, 31.0 \%, 26.3 \%$, and $39.8 \%$ in the G5, G6, G8, and G9 groups, respectively as compared to the G2 group. Additionally, the level of MIP-2 was reduced by $26.7 \%$ and $19.5 \%$ in the G6 and G8 groups, respectively as compared to the G4 group.

Besides, the level of MMP-9 was significantly ( $\mathrm{p} \leq 0.001$ ) reduced by $15.1 \%, 21.5 \%$, and $34 \%$ in the G6, G8, and G9 groups, respectively as compared to the G4 group. Altogether, the data imply the antioxidant and anti-inflammatory potential of the Biofield Energy Treated test formulation and Biofield Energy Treatment per se along with preventive measure on the animal with respect to various inflammatory conditions that might be beneficial various types of systemic inflammatory disorders specially sepsis, trauma, septic shock or any types of cardiac injuries. Therefore, the results showed the significant slowdown the inflammation-related disease progression and its complications/symptoms in the preventive Biofield Energy Treatment group per se and/or Biofield Energy Treated Test formulation groups (viz. G6, G7, G8, and G9) comparatively with the disease control group.

Keyword: Biofield Treatment; Inflammatory cytokines; The Trivedi Effect®; ELISA; SIRS; Antioxidant; Heart biomarker

Abbreviations: SIRS: Systemic inflammatory response syndrome; MPO: Myeloperoxidase; SOD: superoxide dismutase; LPO: Lipid peroxidase; CAD: Coronary artery disease; LDL: Low-density lipoprotein; CAM: Complementary and Alternative Medicine; NCCAM: National Center for Complementary/Alternative Medicine; NCCIH: National Centre of Complementary and Integrative Health; SD: Sprague Dawley; LPS: Lipopolysaccharide; SEM: Standard error of mean; RA: Rheumatoid arthritis; AD: Addison disease

\section{Introduction}

Cardiovascular diseases are very common cause of health burden worldwide [1]. Heart disease is the leading cause of death for all age's population in the United States. In 2010, coronary artery disease (CAD) accounted for one in six deaths in the United States [2]. However, in 2020, one person dies every 
36 seconds that's one in every four deaths in the United States from cardiovascular disease $[3,4]$. Oxygen free radicals promote low-density lipoprotein (LDL) peroxidation, and increase the number of foam cells, that causes vascular endothelial cell injury, and induce expression of proinflammatory cytokines [5]. Cytokines (TNF- $\alpha$, TGF- $\beta$ ) and interleukins (IL-1, IL-4, IL-6, IL-8, and IL-18) are responsible for the development of various inflammatory pathologies of various vital systems such as cardiac, brain, renal, lymphatic, etc. [6]. MIP-2 is produced by a variety of cells in response to infection or injury. It is regulated by multiple factors like by signalling through Toll-like receptor 2 (TLR2), TLR3, and TLR4 in response to diverse pathogens [7]. Superoxide dismutases (SODs) an antioxidant enzyme and also acts as a good therapeutic agent against reactive oxygen species-mediated diseases [8]. Thus, in order to study the change in heart cytokines in presence of Cecal Slurry, LPS and E. coli-induced systemic inflammatory response syndrome model in Sprague Dawley rats, a novel test formulation was designed with the combination of vital minerals (selenium, zinc, iron, calcium, and magnesium), essential vitamins (cyanocobalamin, ascorbic acid, pyridoxine $\mathrm{HCl}$, vitamin $\mathrm{E}$, and cholecalciferol), and nutraceuticals ( $\beta$-carotene, Ginseng, cannabidiol isolate (CBD)). All the minerals and vitamins used in the test formulation have significant functional role to provide vital physiological responses $[9,10]$. Besides, cannabidiol itself has wide range of pharmacological profile and has been reported to role in different disorders $[11,12]$, while ginseng extract is regarded as the one of the best immune booster for overall immunity [13]. The present study was aimed to evaluate the antioxidant and anti-inflammatory potential of the Biofield Energy Treated Proprietary Test Formulation and Biofield Energy Treatment per se to the animals on Cecal Slurry, LPS and E. coli-induced systemic inflammatory response syndrome model in Sprague Dawley rats.

Biofield Energy Healing Treatment has been reported with significant effects against various disorders and defined as one of the best Complementary and Alternative Medicine (CAM) treatment approach [14-16]. National Center for Complementary/ Alternative Medicine (NCCAM) recommended CAM with several clinical benefits as compared with the conventional treatment approach [17]. National Centre of Complementary and Integrative Health (NCCIH) accepted Biofield Energy Healing as a CAM health care approach in addition to other therapies such as deep breathing, natural products, Tai Chi, yoga, therapeutic touch, Johrei, Reiki, pranic healing, chiropractic/osteopathic manipulation, guided imagery, meditation, massage, homeopathy, hypnotherapy, special diets, relaxation techniques, movement therapy, mindfulness, Ayurvedic medicine, traditional Chinese herbs and medicines in biological systems $[18,19]$. The Trivedi Effect $®$-Consciousness Energy Healing Treatment was scientifically reported on various disciplines such as in the materials science [20,21], agriculture science [22], antiaging [23], gut health [24], nutraceuticals [25], pharmaceuticals [26], overall human health and wellness. In this study, the authors want to evaluate the effect of the Biofield Energy Treatment (the Trivedi Effect $\AA$ ) on the given novel test formulation and Biofield Energy Treatment per se to the animals on heart biomarkers in presence of Cecal Slurry, LPS and E. coliinduced systemic inflammatory response syndrome model in in Sprague Dawley rats using standard ELISA assay.

\section{Material and Methods}

\section{Chemicals and Reagents}

Pyridoxine hydrochloride (vitamin B6), zinc chloride, magnesium (II) gluconate, and $\beta$-carotene (retinol, provit A) were purchased from TCI, Japan. Cyanocobalamin (vitamin B12), calcium chloride, vitamin E (Alpha-Tocopherol), cholecalciferol (vitamin D3), iron (II) sulfate, and carboxymethyl cellulose sodium were procured from Sigma-Aldrich, USA. Ascorbic acid (vitamin C) and sodium selenate were obtained from Alfa Aesar, India. Panax ginseng extract and cannabidiol isolate were obtained from Panacea Phytoextracts, India and Standard Hemp Company, USA, respectively. Dexamethasone was obtained from Clear synth, India. For the estimation of heart antioxidant and inflammatory biomarker panels, such as myeloperoxidase (MPO), superoxide dismutase (SOD), lipid peroxidation (LPO), tumour necrosis factor alpha (TNF- $\alpha$ ), interleukin-6 (IL-6), macrophage inflammatory protein-2 (MIP-2), and matrix metallopeptidase 9 (MMP-9) were procured from CUSABIO, USA using specific ELISA kits.

\section{Maintenance of Animal}

Randomly breed male Sprague Dawley (SD) rats with body weight ranges from 200 to 300 gm were used in this study. The animals were purchased from M/s. Vivo Bio Tech, Hyderabad, India. Animals were randomly divided into nine groups based on their body weights consist of 10-12 animals of each group. They were kept individually in sterilized polypropylene cages with stainless steel top grill having provision for holding pellet feed and drinking water bottle fitted with stainless steel sipper tube. The animals were maintained as per standard protocol throughout the experiment.

\section{Consciousness Energy Healing Strategies}

Each ingredient of the novel test formulation was divided into two parts. One part of the test compound did not receive any sort of treatment and were defined as the untreated or control sample. The second part of the test formulation was treated with the Trivedi Effect ${ }^{\circledR}$ - Energy of Consciousness Healing Treatment (Biofield Energy Treatment) by a renowned Biofield Energy Healer, Mr. Mahendra Kumar Trivedi under laboratory conditions for $\sim 3$ minutes. Besides, three group of animals also received Biofield Energy Healing Treatment (known as the Trivedi Effect ${ }^{\circledR}$ ) by Mr. Mahendra Kumar Trivedi under similar laboratory conditions for $\sim 3$ minutes. The Blessing (prayer)/Treatment was given to the test items/animals (present in the laboratory of Dabur Research Foundation, near New Delhi, India), remotely from USA for about 3 minutes via online web-conferencing platform. After that, the Biofield Energy Treated samples was kept in the similar sealed condition and used as per the study plan. In the same manner, the 
control test formulation group was subjected to "sham" healer for $\sim 3$ minutes treatment, under the same laboratory conditions. The "sham" healer did not have any knowledge about the Biofield Energy Treatment. The Biofield Energy Treated animals were also taken back to experimental room for further proceedings.

\section{Experimental Procedure}

Seven days after acclimatization, animals were randomized and grouped based on the body weight. The test formulation was prepared freshly prior to dosing and administered to the animals using an oral intubation needle attached to an appropriately graduated disposable syringe. The dose volume was $10 \mathrm{~mL} / \mathrm{kg}$ in morning and evening based on body weight. The experimental groups were divided as G1 as normal control (vehicle, 0.5\% w/v CMC-Na); G2 as disease control (Cecal Slurry, LPS and E. coli + $0.5 \%$ CMC-Na); G3 as reference item (Cecal Slurry, LPS and E. coli + Dexamethasone); G4 includes Cecal Slurry, LPS and E. coli along with untreated test formulation; G5 as Cecal Slurry, LPS and E. coli along with the Biofield Energy Treated test formulation; G6 group includes Cecal Slurry, LPS and E. coli along with Biofield Energy Treatment per se to animals from day -15; G7 as Cecal Slurry, LPS and E. coli along with the Biofield Energy Treated test formulation from day -15; G8 group includes Cecal Slurry, LPS and E. coli along with Biofield Energy Treatment per se plus the Biofield Energy Treated test formulation from day -15 , and G9 group denoted Cecal Slurry, LPS and E. coli along with Biofield Energy Treatment per se animals plus the untreated test formulation. Dosing for groups G7 and G8 were started on Day -15 and continued till end of the experiment. However, Group G1 to G5 and G9 animals were dosed with respective formulations from Day 1 and continued till the end of the experiment. Group G6 animals received Biofield Energy Treatment on Day-15 and were not dosed throughout the experimental period. At the end of the experimental period ( 8 weeks treatment), the animals were sacrifice and heart were collected, homogenised, and the supernatant subjected for estimation of antioxidants (MPO, SOD, and LPO) and cytokines (TNF alpha, IL-6, MIP-2, and MMP-9).

\section{Induction of Systemic Inflammatory Response Syndrome (SIRS) Model}

A combination model of sepsis was developed in SD rats by administering Cecal slurry (from donor animals, intraperitoneally, at the dose of $400 \mathrm{mg} / \mathrm{kg}$ ) in combination with LPS (at the dose of $100 \mu \mathrm{g} / \mathrm{animal}$ ) and E. coli [Escherichia coli; $0.2 \mathrm{~mL}$ (2M CFU)/ animal]). The animals were monitored for various parameters for up to 56 days after disease (SIRS) induction. Ten Donor ( $\sim 20$ weeks old) rats were anesthetized. A midline laparotomy was performed on them and the cecum was extruded. A $0.5 \mathrm{~cm}$ incision was made on the anti-mesenteric surface of the cecum, and the cecum was squeezed to expel the feces. The feces from different donor animals was collected and weighed. Immediately after collection, the feces were pooled, diluted 1:3 with $5 \%$ dextrose solution and filtered to get a homogeneous suspension. Bacterial viability in the cecal slurry was analyzed. Cecal slurry prepared from donor rats was injected intraperitoneally into experimental rats (G2 to G9) at the dose of $400 \mathrm{mg} / \mathrm{kg}$ within 2 hours of preparation. After 3 hours, lipopolysaccharide (LPS) at the dose of $100 \mu \mathrm{g} / \mathrm{animal}$, and gram-negative viable bacteria such as E. coli [0.2 mL (2M CFU)/ animal] were injected, intraperitoneally (G2 to G9).

\section{Preparation of Sample for the Estimation of Antioxidant and Cytokines}

With the continued treatment to the respective groups of 8th week of the experimental period, all the animals were sacrificed, heart were collected, homogenized and subjected for the estimation of antioxidants and cytokines. The tissue from all the groups was stored at $-20^{\circ} \mathrm{C}$ for further estimation. Alternatively, aliquot all the samples and store samples at $-20^{\circ} \mathrm{C}$ or $-80^{\circ} \mathrm{C}$. Avoid repeated freeze-thaw cycles, which may alter the level of cytokines during final calculations.

\section{Estimation of Antioxidants and Cytokine Levels}

The heart from all the groups was subjected for the estimation of level of antioxidants such as MPO (CSB-E08722r), SOD (706002), and LPO (700870) and cytokines such as TNF- $\alpha$ (CSBE11987r), IL-6 (CSB-E04640r), MIP-2 (CSB-E07419r), and MMP9 (CSB-E08008r). All the biomarker panel was estimation using ELISA method as per manufacturer's recommended standard procedure. This was a quantitative method and the principle was based on the binding of antigen and antibody in sandwich manner assay.

\section{Statistical Analysis}

The data were represented as mean \pm standard error of mean (SEM) and subjected to statistical analysis using Sigma-Plot statistical software (Version 11.0). For multiple comparison Oneway analysis of variance (ANOVA) followed by post-hoc analysis by Dunnett's test and for between two groups comparison Student's t-test was performed. The $\mathrm{p} \leq 0.05$ was considered as statistically significant.

\section{Results and Discussion}

\section{Assessment of Antioxidants in Heart Homogenate}

Estimation of Myeloperoxidase (MPO): Myeloperoxidase (MPO) was estimated in the presence of the test formulation and the data are graphically shown in Figure 1. The data suggested that the disease control (Cecal Slurry, LPS and E. coli $+0.5 \%$ CMC$\mathrm{Na}$ ) $+0.5 \% \mathrm{CMC}$ ) group (G2) showed value of MPO as $2.41 \pm 0.0 .28$ $\mathrm{ng} / \mathrm{mL}$, which was increased by $0.45 \%$ as compared with the normal control (G1, $2.40 \pm 0.1 \mathrm{ng} / \mathrm{mL}$ ). However, positive control (Dexamethasone) treatment (G3) showed the level of MPO in heart i.e., $2.80 \pm 0.14 \mathrm{ng} / \mathrm{mL}$.

The level of MPO in heart tissues was decreased by $9.98 \%$ and $12.07 \%$ in the G5 (Cecal Slurry, LPS and E. coli along with the Biofield Energy Treated test formulation) and G6 (Cecal Slurry, 
LPS and E. coli along with Biofield Energy Treatment per se to animals from day -15) groups, respectively as compared to the untreated test formulation (G4) group. High expression of MPO level in circulation are associated with inflammation and increased oxidative stress that leads to cardiovascular disease (CVDs) like coronary artery disease, congestive heart failure, arterial hypertension, pulmonary arterial hypertension, myocardial ischemia, stroke, cardiac arrhythmia and venous thrombosis [27]. Multiple lines of evidence suggested that MPO may play a role in atherogenesis in humans. However, MPO has little role as atheroprotective in the murine atherosclerosis model [28]. MPO plays an important role in the host defense against different types of bacteria and viruses. MPO is also an important enzyme in the inflammatory process, and inflammation is a key component in the development and progression of atherosclerotic and other forms of cardiovascular disease [29]. Overall, in this experiment the Biofield Energy Treated test formulation and Biofield Energy Healing Treatment per se reduced the level of MPO in the heart tissues, which could be helpful for the management of oxidative stress and inflammatory conditions related to cardiovascular disorders.

Figure 1 The effect of the test formulation on the level of heart myeloperoxidase (MPO) in Sprague Dawley rats. G1 as normal control (vehicle, $0.5 \% \mathrm{w} / \mathrm{v} \mathrm{CMC-Na);} \mathrm{G2} \mathrm{as} \mathrm{disease} \mathrm{control} \mathrm{(Cecal}$ Slurry, LPS and E. coli + 0.5\% CMC-Na); G3 as reference item (Cecal Slurry, LPS and E. coli + Dexamethasone); G4 includes Cecal Slurry, LPS and E. coli along with untreated test formulation; G5 as Cecal Slurry, LPS and E. coli along with the Biofield Energy Treated test formulation; G6 group includes Cecal Slurry, LPS and E. coli along with Biofield Energy Treatment per se to animals from day -15; G7 as Cecal Slurry, LPS and E. coli along with the Biofield Energy Treated test formulation from day -15; G8 group includes Cecal Slurry, LPS and E. coli along with Biofield Energy Treatment per se plus the Biofield Energy Treated test formulation from day -15, and G9 group denoted Cecal Slurry, LPS and E. coli along with Biofield Energy Treatment per se animals plus the untreated test formulation. Values are presented as mean \pm SEM $(n=6-9)$.

Estimation of Superoxide Dismutase (SOD): The effect of the test formulation and Biofield Energy Treatment per se was assessed by estimating the level of heart superoxide dismutase (SOD), and the results are graphically presented in the Figure 2. The disease control (Cecal Slurry, LPS and E. coli $+0.5 \%$ CMC-Na) $+0.5 \% \mathrm{CMC}$ ) group (G2) showed value of SOD as $3.79 \pm 0.13 \mathrm{U} /$ $\mathrm{mL}$, which was decreased by $3.2 \%$ as compared to the normal control group i.e., $4.10 \pm 0.18 \mathrm{U} / \mathrm{mL}$. However, positive control (Dexamethasone) treatment (G3) showed the level of SOD in heart i.e., $4.49 \pm 0.22 \mathrm{U} / \mathrm{mL}$, which was increased by $13.3 \%$ as compared to $\mathrm{G} 2$.

The level of SOD was increased significantly by $1.27 \%, 19.03 \%$ $(\mathrm{p} \leq 0.05), 17.26 \%(\mathrm{p} \leq 0.05), 6.15 \%$, and $11.81 \%(\mathrm{p} \leq 0.05)$ in the G5 (Cecal Slurry, LPS and E. coli along with the Biofield Energy Treated test formulation); G6 (Cecal Slurry, LPS and E. coli along with Biofield Energy Treatment per se to animals from day -15), G7 as Cecal Slurry, LPS and E. coli along with the Biofield Energy Treated test formulation from day -15; G8 (Cecal Slurry, LPS and E. coli along with Biofield Energy Treatment per se plus the Biofield Energy Treated test formulation from day -15), and G9 (Cecal Slurry, LPS and E. coli along with Biofield Energy Treatment per se animals plus the untreated test formulation) groups, respectively with reference to disease control group (G2). Further, the level of SOD was significantly increased by $3.8 \%, 22.01 \%$ ( $\mathrm{p} \leq 0.05)$, $20.19 \%$ ( $\mathrm{p} \leq 0.05$ ), $8.80 \%$, and $14.6 \%$ in the G5, G6, G7, G8, and G9 groups, respectively with reference to untreated test formulation group (G4). Studies in the heart suggest that extra-cellular SOD is important for preventing oxidative injury after myocardial infarction and may contribute to cardiac remodeling [30]. SOD is one of the main intracellular antioxidant defence mechanisms is associated with cardiac and vascular defects leads to hypertension and atherosclerosis. It is also protecting thermogenesis [31]. Therefore, in this experiment the Biofield Energy Treated test formulation significantly increased the level of heart SOD, which could be beneficial inflammation and oxidative damage.

Figure 2: The level of superoxide dismutase (SOD) measured in heart tissue in Sprague Dawley rats after administration with Biofield Treated test formulation and Biofield Treatment per se. G1 as normal control (vehicle, 0.5\% w/v CMC-Na); G2 as disease control (Cecal Slurry, LPS and E. coli $+0.5 \%$ CMC-Na); G3 as reference item (Cecal Slurry, LPS and E. coli + Dexamethasone); G4 includes Cecal Slurry, LPS and E. coli along with untreated test formulation; G5 as Cecal Slurry, LPS and E. coli along with the Biofield Energy Treated test formulation; G6 group includes Cecal Slurry, LPS and E. coli along with Biofield Energy Treatment per se to animals from day -15; G7 as Cecal Slurry, LPS and E. coli + Biofield Energy Treated test formulation from day -15; G8 group includes Cecal Slurry, LPS and E. coli + Biofield Energy Treatment per se + Biofield Energy Treated test formulation from day -15 , and G9 group denoted Cecal Slurry, LPS and E. coli along with Biofield Energy Treatment per se animals plus the untreated test formulation. Values are presented as mean $\pm \operatorname{SEM}(n=6-9) .{ }^{*} \mathrm{p} \leq 0.05$ vs. G2 and \#p $\leq 0.05$ vs. G4.

Estimation of Lipid Peroxidation (LPO): The level of lipid peroxidation (LPO) end product in terms of malondialdehyde (MDA) was detected in all the experimental groups and the data are presented in Figure 3. The disease control (Cecal Slurry, LPS and E. coli $+0.5 \%$ CMC-Na) group (G2) and positive control (Dexamethasone) treatment (G3) groups showed value of MDA as $4.20 \pm 0.48 \mu \mathrm{M}$ and $4.33 \pm 0.37 \mu \mathrm{M}$, respectively.

The level of MDA was decreased by $5.6 \%, 2.9 \%$, and $18 \%$ in the G7 as Cecal Slurry, LPS and E. coli along with the Biofield Energy Treated test formulation from day -15; G8 (Cecal Slurry, LPS and E. coli along with Biofield Energy Treatment per se plus the Biofield Energy Treated test formulation from day -15), and G9 (Cecal Slurry, LPS and E. coli along with Biofield Energy Treatment per se animals plus the untreated test formulation) 
groups, respectively with reference to disease control group (G2). Additionally, the level of MDA was significantly reduced by $4.1 \%$, $11.1 \%, 8.5 \%$, and $22.8 \%(\mathrm{p} \leq 0.05)$ in the G5 (Cecal Slurry, LPS and E. coli along with the Biofield Energy Treated test formulation), G7, G8, and G9 groups, respectively as compared to the untreated test formulation group (G4). Oxidative stress and inflammation are two major mechanisms leading to atherosclerosis. Under oxidative stress, phospholipids and cholesterol esters can readily oxidized through a free radical-induced lipid peroxidation (LPO) process to form a complex mixture of oxidation products. These oxidized lipids are responsible for inflammatory responses in atherosclerosis by interacting with immune cells (macrophages) and endothelial cells [32]. The LPO products are highly reactive and causes selective alterations in cell signaling, protein and DNA damage, and cytotoxicity [33]. In this experiment, the Biofield Energy Treated preventive groups significantly reduced the level of LPO in heart tissues, which could be beneficial inflammation and oxidative damage in heart.

Figure 3: The level of heart lipid peroxidation (LPO) in Sprague Dawley rats after dosed with the Biofield Treated test formulation and Biofield Energy Healing per se. G1 as normal control (vehicle, $0.5 \% \mathrm{w} / \mathrm{v} \mathrm{CMC}-\mathrm{Na}$ ); G2 as disease control (Cecal Slurry, LPS and E. coli $+0.5 \%$ CMC-Na); G3 as reference item (Cecal Slurry, LPS and E. coli + Dexamethasone); G4 includes Cecal Slurry, LPS and $E$. coli along with untreated test formulation; G5 as Cecal Slurry, LPS and E. coli along with the Biofield Energy Treated test formulation; G6 group includes Cecal Slurry, LPS and E. coli along with Biofield Energy Treatment per se to animals from day -15; G7 as Cecal Slurry, LPS and E. coli + Biofield Energy Treated test formulation from day -15; G8 group includes Cecal Slurry, LPS and E. coli + Biofield Energy Treatment per se plus the Biofield Energy Treated test formulation from day -15, and G9 group denoted Cecal Slurry, LPS and E. coli along with Biofield Energy Treatment per se animals plus the untreated test formulation. Values are presented as mean \pm SEM $(n=6-9) .{ }^{*} \mathrm{p} \leq 0.05$ vs. G4.

\section{Assessment of Cytokines in Heart Homogenate}

Estimation of Tumour Necrosis Factor Alpha (TNF- $\alpha$ ) The expression of heart tumour necrosis factor alpha (TNF- $\alpha$ ) in Sprague Dawley rats after administration of Biofield Treated test formulation and exposure of Biofield Treatment to the animals per se, and the results are shown in Figure 4. The disease control (Cecal Slurry, LPS and E. coli $+0.5 \%$ CMC-Na) group (G2) showed value of TNF- $\alpha$ as $204.12 \pm 46.49 \mathrm{pg} / \mathrm{mL}$, which was significantly ( $\mathrm{p} \leq 0.01$ ) increased by $399 \%$ as compared with the normal control (G1, $40.91 \pm 3.85 \mathrm{pg} / \mathrm{mL})$.

Further, the positive control (Dexamethasone) treatment (G3) showed significant $(\mathrm{p} \leq 0.01)$ decreased TNF- $\alpha$ level by $66 \%$ i.e., $69.31 \pm 8.52 \mathrm{pg} / \mathrm{mL}$ as compared to the G2 group. TNF- $\alpha$ level was decreased significantly by $25.97 \%, 40.28 \%$ ( $\mathrm{p} \leq 0.01)$, $24.86 \%, 36.54 \%$ ( $\mathrm{p} \leq 0.01$ ), and $34.30 \%$ in the G5 (Cecal Slurry, LPS and E. coli along with the Biofield Energy Treated test formulation); G6 (Cecal Slurry, LPS and E. coli along with Biofield
Energy Treatment per se to animals from day -15), G7 as Cecal Slurry, LPS and E. coli along with the Biofield Energy Treated test formulation from day -15; G8 (Cecal Slurry, LPS and E. coli + Biofield Energy Treatment per se + Biofield Energy Treated test formulation from day -15), and G9 (Cecal Slurry, LPS and E. coli + Biofield Energy Treatment per se animals + untreated test formulation) groups, respectively as compared to the disease control group (G2). Further, the expression of TNF- $\alpha$ was reduced by $16.2 \%, 10.9 \%$, and $7.8 \%$ in the G6, G8, and G9 groups, respectively as compared to the untreated test formulation group (G4). Pro-inflammatory cytokines are consistently increased in congestive heart failure. In the cardiovascular system, TNF- $\alpha$ activate signal transduction pathways may causes vascular dysfunction, development, and progression of atherosclerosis, and thus ultimately leads to myocardial infarction and heart failure [34]. Another, study reported that TNFa is responsible for the progression of heart failure as a mediator of myocardial dysfunction and adverse remodeling, that leads to elevated levels of circulating TNF $\alpha$ in heart failure patients as compared with the control [35]. Moreover, TNF modulates both cardiac contractility and peripheral resistance, the two most important haemodynamic determinants of cardiac function [36]. Therefore, here the Biofield Energy Treated test formulation and Biofield Energy Treatment per se significantly reduced the level of TNF- $\alpha$, which could be beneficial in the cardiovascular disorders.

Figure 4: The expression of heart tumour necrosis factor alpha (TNF- $\alpha$ ) in Sprague Dawley rats after administration of Biofield Treated test formulation and exposure of Biofield Treatment to the animals per se. G1 as normal control (vehicle, 0.5\% w/v CMC$\mathrm{Na}$ ); G2 as disease control (Cecal Slurry, LPS and E. coli $+0.5 \%$ CMC-Na); G3 as reference item (Cecal Slurry, LPS and E. coli + Dexamethasone); G4 includes Cecal Slurry, LPS and E. coli along with untreated test formulation; G5 as Cecal Slurry, LPS and E. coli along with the Biofield Energy Treated test formulation; G6 group includes Cecal Slurry, LPS and E. coli along with Biofield Energy Treatment per se to animals from day -15; G7 as Cecal Slurry, LPS and E. coli + Biofield Energy Treated test formulation from day -15; G8 group includes Cecal Slurry, LPS and E. coli + Biofield Energy Treatment per se plus the Biofield Energy Treated test formulation from day -15, and G9 group denoted Cecal Slurry, LPS and E. coli along with Biofield Energy Treatment per se animals plus the untreated test formulation. Values are presented as mean $\pm \operatorname{SEM}(\mathrm{n}=6-9) . \# \# \mathrm{p} \leq 0.01$ vs. G1 and ${ }^{* *} \mathrm{p} \leq 0.01$ vs. G2.

\section{Estimation of Interleukin-6 (IL-6)}

The expression of heart interleukin-6 (IL-6) in Sprague Dawley rats after administration of Biofield Treated test formulation and exposure of Biofield Treatment to the animals per se, and the results are graphically shown in Figure 5. The disease control (Cecal Slurry, LPS and E. coli $+0.5 \%$ CMC-Na) group (G2) showed value of IL-6 as $19.05 \pm 2.29 \mathrm{pg} / \mathrm{mL}$, which was significantly ( $\mathrm{p} \leq 0.001$ ) increased by $98.7 \%$ as compared with the normal control (G1, $9.59 \pm 0.44 \mathrm{pg} / \mathrm{mL}$ ). Further, the positive control 
(Dexamethasone) treatment (G3) showed the level of IL-6 i.e., $10.46 \pm 0.71 \mathrm{pg} / \mathrm{mL}$, which was decreased by $45.1 \%$ as compared to the G2 group. The level of IL- 6 was significantly decreased by $23.5 \%$ ( $\mathrm{p} \leq 0.001), 31.0 \%$ ( $\mathrm{p} \leq 0.001), 19.5 \%, 26.3 \%$ ( $\mathrm{p} \leq 0.001)$, and $39.8 \%(\mathrm{p} \leq 0.001$ ) in the G5 (Cecal Slurry, LPS and E. coli along with the Biofield Energy Treated test formulation); G6 (Cecal Slurry, LPS and E. coli along with Biofield Energy Treatment per se to animals from day -15), G7 as Cecal Slurry, LPS and E. coli along with the Biofield Energy Treated test formulation from day -15; G8 (Cecal Slurry, LPS and E. coli along with Biofield Energy Treatment per se plus the Biofield Energy Treated test formulation from day -15), and G9 (Cecal Slurry, LPS and E. coli along with Biofield Energy Treatment per se animals plus the untreated test formulation) groups, respectively, as compared to the disease control group (G2).

Further, the expression of IL- 6 was decreased by 3.2\%, 12.7\%, $6.7 \%$, and $23.9 \%$ in G5, G6, G8, and G9 groups, correspondingly with reference to untreated test formulation (G4) group. Based on the one of the studies from myocardial infarction which shows that IL-6 signaling plays a causal role in cardiovascular disease [37]. The patients with high titre of circulating inflammatory biomarkers get more susceptible to cardiovascular events. It is more common in patients with high IL-6, associated with an increased incidence of myocardial infarction and mortality among patients with acute coronary syndromes [38]. There is an extensive body of the literature that supports that an increased level of inflammatory cytokine like IL-6 is associated with acute ischemic conditions and predictor of coronary artery disease [39]. Overall, in this experiment the Biofield Energy Treated test formulation and Biofield Energy Treatment per se significantly reduced the level of IL-6, which could be reduce the risks of inflammatory diseases specially in the heart.

Figure 5: The expression of heart interleukin-6 (IL-6) in Sprague Dawley rats after administration of Biofield Treated test formulation and exposure of Biofield Treatment to the animals per se. G1 as normal control (vehicle, $0.5 \% \mathrm{w} / \mathrm{v} \mathrm{CMC}-\mathrm{Na}$ ); G2 as disease control (Cecal Slurry, LPS and E. coli + 0.5\% CMC-Na); G3 as reference item (Cecal Slurry, LPS and E. coli + Dexamethasone); G4 includes Cecal Slurry, LPS and E. coli along with untreated test formulation; G5 as Cecal Slurry, LPS and E. coli along with the Biofield Energy Treated test formulation; G6 group includes Cecal Slurry, LPS and E. coli along with Biofield Energy Treatment per se to animals from day -15; G7 as Cecal Slurry, LPS and E. coli + Biofield Energy Treated test formulation from day -15; G8 group includes Cecal Slurry, LPS and E. coli + Biofield Energy Treatment per se plus the Biofield Energy Treated test formulation from day -15, and G9 group denoted Cecal Slurry, LPS and E. coli along with Biofield Energy Treatment per se animals plus the untreated test formulation. Values are presented as mean \pm SEM $(n=6-9)$. \#\#\#p $\leq 0.001$ vs. G1 and ***p $\leq 0.001$ vs. G2.

Estimation of Macrophage Inflammatory Protein-2 (MIP2): The expression of macrophage inflammatory protein-2 (MIP-
2) in heart tissue after administration of the Biofield Treated/ Blessed proprietary test formulation and Biofield Energy Healing Treatment per se to the animals was estimated, and the results are graphically shown in Figure 6. The disease control (Cecal Slurry, LPS and E. coli + 0.5\% CMC-Na) group (G2) showed value of MIP2 as $1734.78 \pm 237.57 \mathrm{pg} / \mathrm{mL}$, which was decreased by $51.8 \%$ as compared with the normal control (G1, $3598.50 \pm 395.77 \mathrm{pg} / \mathrm{mL}$ ).

Further, the positive control (Dexamethasone) treatment (G3) showed increased heart MIP-2 level by $40.6 \%$ i.e., $2438.50 \pm$ $255.71 \mathrm{pg} / \mathrm{mL}$ as compared to the G2 group. The level of MIP-2 was decreased by $26.7 \%$ and $19.5 \%$ in the G6 (Cecal Slurry, LPS and $E$. coli along with Biofield Energy Treatment per se to animals from day -15) and G8 (Cecal Slurry, LPS and E. coli along with Biofield Energy Treatment per se plus the Biofield Energy Treated test formulation from day -15) groups, respectively as compared to the untreated test formulation group (G4). The MIP-2 is a murine counterpart of IL-8. MIP-2 is a naturally occurring inflammatory cytokine biomarker in myocardium and its expression is increased during myocarditis. Study reported that plasma MIP-2 levels are significantly elevated in mice on days 7 and 14 of post-infection with encephalomyocarditis (EMC) virus [40]. Taken together, our data suggest that the Biofield Energy Treated test formulation and Biofield Energy Treatment per se reduced the level of MIP2 in heart tissues, which could prevent the cardiovascularinflammation.

Figure 6: The expression of heart macrophage inflammatory protein-2 (MIP-2) in Sprague Dawley rats after treatment with Biofield Treated test formulation and Biofield Energy treatment per se to the animals. G1 as normal control (vehicle, 0.5\% w/v CMC-Na); G2 as disease control (Cecal Slurry, LPS and E. coli + $0.5 \%$ CMC-Na); G3 as reference item (Cecal Slurry, LPS and E. coli + Dexamethasone); G4 includes Cecal Slurry, LPS and E. coli along with untreated test formulation; G5 as Cecal Slurry, LPS and E. coli along with the Biofield Energy Treated test formulation; G6 group includes Cecal Slurry, LPS and E. coli along with Biofield Energy Treatment per se to animals from day -15; G7 as Cecal Slurry, LPS and E. coli + Biofield Energy Treated test formulation from day -15; G8 group includes Cecal Slurry, LPS and E. coli + Biofield Energy Treatment per se plus the Biofield Energy Treated test formulation from day -15, and G9 group denoted Cecal Slurry, LPS and E. coli along with Biofield Energy Treatment per se animals plus the untreated test formulation. Values are presented as mean \pm SEM (n=6-9).

Estimation of Matrix Metallopeptidase-9 (MMP-9): The expression of matrix metallopeptidase-9 (MMP-9) in heart tissue after administration of the Biofield Treated/Blessed proprietary test formulation and Biofield Energy Healing Treatment per se to the animals was estimated, and the results are graphically presented in Figure 7. The disease control (Cecal Slurry, LPS and $E$. coli $+0.5 \%$ CMC-Na) group (G2) showed value of MMP-9 as 155.85 $\pm 12.62 \mathrm{pg} / \mathrm{mL}$, which was increased by $13.8 \%$ as compared with the normal control (G1,136.96 $\pm 4.68 \mathrm{pg} / \mathrm{mL})$. Further, the positive 
control (Dexamethasone) treatment (G3) group decreased MMP9 level by $8.1 \%$ i.e., $143.28 \pm 7.66 \mathrm{pg} / \mathrm{mL}$ as compared to the $\mathrm{G} 2$ group.

The level of MMP-9 was decreased by $6.4 \%, 9 \%, 2 \%, 15.8 \%$, and $29.3 \%$ in the G5 (Cecal Slurry, LPS and E. coli along with the Biofield Energy Treated test formulation); G6 (Cecal Slurry, LPS and E. coli along with Biofield Energy Treatment per se to animals from day -15); G7 (Cecal Slurry, LPS and E. coli along with the Biofield Energy Treated test formulation from day -15); G8 (Cecal Slurry, LPS and E. coli along with Biofield Energy Treatment per se plus the Biofield Energy Treated test formulation from day -15), and G9 (Cecal Slurry, LPS and E. coli along with Biofield Energy Treatment per se animals plus the untreated test formulation) groups, respectively, as compared to the disease control group (G2).

Besides, the level of MMP-9 was significantly reduced by $12.6 \%$, $15.1 \%(\mathrm{p} \leq 0.001), 8.6 \%, 21.5 \%(\mathrm{p} \leq 0.001)$, and $34 \%(\mathrm{p} \leq 0.001)$ in the G5, G6, G7, G8, and G9 groups, respectively with reference to untreated test formulation (G4) group. MMP-9 is one of the most widely investigated MMPs. MMP-9 expression has increases during cardiovascular disorders like hypertension, atherosclerosis, and myocardial infarction. MMP-9 degrades extracellular matrix proteins and activates cytokines and chemokines to regulate pathological remodeling processes that involve inflammation and fibrosis in cardiovascular disease [41]. According to one of the extensive research work done by Swedish researchers, they found the high level of MMP-9 in coronary artery disease (coronary artery ectasia) patients and a predictor of increased mortality in that patients [42]. In this study, the Biofield Energy Treated test formulation and Biofield Energy Treatment per se significantly reduced the level of MMP-9, which could be beneficial to combat inflammatory disease conditions in the cardiovascular patients.

Figure 7: The effect of the test formulation on the level of heart macrophage inflammatory protein-2 (MIP-2) in Sprague Dawley rats. G1 as normal control (vehicle, $0.5 \% \mathrm{w} / \mathrm{v} \mathrm{CMC}-\mathrm{Na}$ ); G2 as disease control (Cecal Slurry, LPS and E. coli + 0.5\% CMC-Na); G3 as reference item (Cecal Slurry, LPS and E. coli + Dexamethasone); G4 includes Cecal Slurry, LPS and E. coli along with untreated test formulation; G5 as Cecal Slurry, LPS and E. coli along with the Biofield Energy Treated test formulation; G6 group includes Cecal Slurry, LPS and E. coli along with Biofield Energy Treatment per se to animals from day -15; G7 as Cecal Slurry, LPS and E. coli + Biofield Energy Treated test formulation from day -15; G8 group includes Cecal Slurry, LPS and E. coli + Biofield Energy Treatment per se + Biofield Energy Treated test formulation from day -15 , and G9 group denoted Cecal Slurry, LPS and E. coli + Biofield Energy Treatment per se animals + untreated test formulation. Values are presented as mean $\pm \operatorname{SEM}(n=6-9)$. ${ }^{* *} \mathrm{p} \leq 0.001$ vs. G4. Experiment includes four preventive maintenance groups (G6, G7, G8 and G9). The findings showed the significant slowdown of inflammation-related symptoms and also reduced the chances of disease susceptibility. All-inclusive, it indicate that the Trivedi Effect ${ }^{\circledR}$ was found to be most effective and benefited to protect different kinds of diseases and also improve the overall health and quality of life.

\section{Conclusions}

Based on the study outcome it was found that the level of MPO was decreased by $12 \%$ in the G6 (Cecal Slurry, LPS and E. coli along with Biofield Energy Treatment per se to animals from day -15) group as compared to the untreated test formulation (G4) group. Expression of SOD was significantly $(\mathrm{p} \leq 0.05)$ increased by $19.03 \%, 17.26 \%$, and $11.81 \%$ in the G6, G7, and G9 groups, respectively as compared to the G4 group. Moreover, the level of TNF- $\alpha$ was significantly reduced by $25.97 \%, 40.28 \%$ ( $\mathrm{p} \leq 0.01$ ), $24.86 \%, 36.54 \%(\mathrm{p} \leq 0.01)$, and $34.30 \%$ in the G6, G7, G8, and G9 groups, respectively with reference to disease control (G2) group. Additionally, IL- 6 was significantly $(\mathrm{p} \leq 0.001)$ decreased by $23.5 \%, 31.0 \%, 26.3 \%$, and $39.8 \%$ in the G5, G6, G8, and G9 groups, respectively as compared to the G2 group. Further, MIP2 was decreased by $26.7 \%$ and $19.5 \%$ in the G6 and G8 groups, respectively as compared to the G4 group. Besides, the level of MMP-9 was significantly ( $\mathrm{p} \leq 0.001$ ) reduced by $15.1 \%, 21.5 \%$, and $34 \%$ in the G6, G8, and G9 groups, respectively as compared to the G4 group.

Altogether, the Biofield Energy Treated test formulation and Biofield Energy Healing Treatment (the Trivedi Effect ${ }^{\circledR}$ ) per se showed significant results with respect to different inflammatory biomarkers (cytokines) in the preventive maintenance group, G6 as well as other preventive maintenance groups (G7, G8, and G9) in Cecal Slurry, LPS and E. coli-induced systemic inflammatory response syndrome model rat model study. It also helped to slowdown the inflammatory disease progression and diseaserelated complications. The study data showed that Biofield Energy Treated Test formulation and Biofield Energy Treatment per se would be one of the best treatment strategies to prevent the manifestation of diseases. Thus, the Biofield Energy Treatment might act as a preventive maintenance therapy to maintain and improve the overall health and quality of life and simultaneously reduce the severity of acute/chronic diseases. The test formulation can also be used against rheumatoid arthritis (RA), fibromyalgia, aplastic anaemia, Addison disease (AD), multiple sclerosis, myasthenia gravis, psoriasis, Crohn's disease, ulcerative colitis, dermatitis, hepatitis, Parkinson's, stroke, etc.

\section{Acknowledgements}

The authors are grateful to Dabur Research Foundation, Trivedi Science, Trivedi Global, Inc., and Trivedi Master Wellness for the assistance and support during the work.

\section{References}

1. Alan Go S, Mozaffarian D, Roger VL, Emelia JB, Jarett DB, et al. (2014) Heart disease and stroke statistics-2014 update: A report from the American heart association. Circulation 129 (3): e28-e292. 
2. Ji-Ren Peng, Ting-Ting Lu, Hao-Teng Chang, Xuan Ge, Bian Huang, et al. (2016) Elevated levels of plasma superoxide dismutases 1 and 2 in patients with coronary artery disease. Bio Med Research International 2016: 9.

3. (2018) Centers for Disease Control and Prevention. Underlying Cause of Death, 1999-2018. CDC WONDER Online Database. Atlanta, GA: Centers for Disease Control and Prevention.

4. Virani SS, Alonso A, Benjamin EJ, Bittencourt MS, Callaway CW, et al. (2020) Heart disease and stroke statistics-2020 update: A report from the American heart association external icon. Circulation 141(9): e139-e596.

5. Singh U, Jialal I (2006) Oxidative stress and atherosclerosis. Pathophysiology 13(3): 129-142.

6. Vishal C, Mehra Vinod S, Ramgolam Jeffrey R, Bender (2005) Cytokines and cardiovascular disease 78: 805-817.

7. Rittner HL, Labuz D, Richter JF, Brack A, Schäfer M, et al. (2007) CXCR1/2 ligands induce p38 MAPK-dependent translocation and release of opioid peptides from primary granules in vitro and in vivo. Brain Behav Immun 21(8): 1021-32.

8. Younus H (2018) Therapeutic potentials of superoxide dismutase. Int J Health Sci (Qassim) 12(3): 88-93.

9. Rayman MP (2000) The importance of selenium to human health. Lancet 356(9225): 233-241.

10. Beard JL, Connor JR (2003) Iron status and neural functioning. Ann Rev Nutr 23: 41-58.

11. Peres FF, Lima AC, Hallak JEC, Crippa JA, Silva RH, et al. (2018) Cannabidiol as a promising strategy to treat and prevent movement disorders? Front Pharmacol 9: 482

12. Nagarkatti P, Pandey R, Rieder SA, Hegde VL, Nagarkatti M (2009) Cannabinoids as novel anti-inflammatory drugs. Future Med Chem 1(7): 1333-1349.

13. Kang S, Min H (2012) Ginseng, the 'Immunity Boost': The effects of Panax ginseng on immune system. J Ginseng Res 36(4): 354-368.

14. Maizes V, Rakel D, Niemiec C (2009) Integrative medicine and patientcentered care. Explore (NY) 5(5): 277-289.

15. Bischof M, Del Giudice E (2013) Communication and the emergence of collective behavior in living organisms: A quantum approach. Mol Biol Int 2013: 987549.

16. Cassidy CM (2004) What does it mean to practice an energy medicine? J Altern Complement Med 10(1): 79-81.

17. Barnes PM, Bloom B, Nahin RL (2007) Complementary and alternative medicine use among adults and children: United States. Natl Health Stat Report 12: 1-23.

18. Fan K wai (2005) National Center for Complementary and Alternative Medicine Website. J Med Libr Assoc 93: 410-412.

19. Wisneski L, Anderson L (2009) The Scientific Basis of Integrative Medicine. CRC Press, Boca Raton, Florida pp. 205.

20. Mahendra Kumar T, Alice B, Dahryn T, Snehasis J (2021) Effect of consciousness energy healing treatment on the metal profile and properties of tellurium. Eng Technol Open Acc 3(5): 555623.

21. Mahendra KT, Alice B, Dahryn T, Snehasis J (2021) Consciousness energy healing treatment impacted the isotopic abundance ratio of 6-Mercaptopurine (6-MP). Nov Appro Drug Des Dev 5(5): 555673.

22. Trivedi MK, Branton A, Trivedi D, Nayak G, Mondal SC, Jana S (2015) Morphological characterization, quality, yield and DNA fingerprinting of biofield energy treated alphonso mango (Mangifera indica L.). Journal of Food and Nutrition Sciences 3: 245-250.
23. Mahendra Kumar Trivedi, Snehasis Jana (2021) Anti-aging activity of biofield energy treated novel proprietary test formulation by assessment of vital biomarkers in cerebrospinal fluid (CSF) in Sprague Dawley rats. On J Neur \& Br Disord 5(2): 2021.

24. Mahendra Kumar T, Snehasis J (2021) Evaluation of biofield energy healing treatment based proprietary test formulation on gut health potential in colon cancer cell line (HT-29). J of Pharmacol \& Clin Res 8(4): 555743.

25. Trivedi MK, Branton A, Trivedi D \& Jana S (2021) Isotopic abundance ratio analysis of consciousness energy healing treated folic acid. Food Nutr Current Res 4(2): 290-295.

26. Mahendra Kumar Trivedi, Alice Branton, Dahryn Trivedi, Snehasis Jana (2020) The consciousness energy healing treatment and its impact on the isotopic abundance ratio analysis of flutamide. Drug Des Int Prop Int J 3(5) 2020.

27. Ndrepepa G (2019) Myeloperoxidase - A bridge linking inflammation and oxidative stress with cardiovascular disease. Clin Chim Acta 493: 36-51.

28. Stephen J Nicholls, Stanley L Hazen (2005) Myeloperoxidase and cardiovascular disease. Arteriosclerosis, Thrombosis, and Vascular Biology 25: 1102-1111.

29. Ikitimur B, Karadag B (2010) Role of myeloperoxidase in cardiology. Future Cardiol 6(5): 693-702.

30. Kliment CR, Suliman HB, Tobolewski JM (2009) Extracellular superoxide dismutase regulates cardiac function and fibrosis. J Mol Cell Cardiol 47(5): 730-742.

31. Manuel A Gómez-Marcos, Ana M Blázquez-Medela, Luis GamellaPozuelo, José I Recio-Rodriguez, Luis García-Ortiz, et al. (2016) Serum superoxide dismutase is associated with vascular structure and function in hypertensive and diabetic patients. Oxidative Medicine and Cellular Longevity 2016: 8.

32. Zhong S, Li L, Shen X, Li Q Xu W, Wang X, et al. (2010) An update on lipid oxidation and inflammation in cardiovascular diseases. Free Radic Biol Med 144: 266-278.

33. Kota V Ramana, Sanjay Srivastava, Sharad S Singhal (2013) Lipid peroxidation products in human health and disease. Oxidative Medicine and Cellular Longevity 2013: 3.

34. Urschel K, Cicha I (2015) TNF- $\alpha$ in the cardiovascular system: From physiology to therapy 2015(7): 9-25.

35. Dunlay SM, Weston SA, Redfield MM, Killian JM, Roger VL (2008) Tumor necrosis factor-alpha and mortality in heart failure: A community study. Circulation 118(6): 625-631.

36. Ferrari R (1991) The role of TNF in cardiovascular disease. Pharmacol Res 40(2): 97-105.

37. Fontes JA, Rose NR, Čiháková D (2015) The varying faces of IL-6: From cardiac protection to cardiac failure. Cytokine 74(1): 62-68.

38. Wainstein MV, Mossmann M, Araujo GN, et al. (2017) Elevated serum interleukin- 6 is predictive of coronary artery disease in intermediate risk overweight patients referred for coronary angiography. Diabetol Metab Syndr 9: 67.

39. Dongfang Su, Zhongxia Li, Xinrui Li, Yuming Chen, Yuan Zhang, et al. (2013) Association between serum interleukin-6 concentration and mortality in patients with coronary artery disease. Mediators of Inflammation 2013: 7

40. Kishimoto C, Kawamata H, Sakai S, Shinohara H, Ochiai H (2001) Enhanced production of macrophage inflammatory protein 2 (MIP2) by in vitro and in vivo infections with encephalomyocarditis virus and modulation of myocarditis with an antibody against MIP-2. J Virol 75(3): 1294-1300. 
41. Yabluchanskiy A, Ma Y, Iyer RP, Hall ME, Lindsey ML (2013) Matrix metalloproteinase -9: Many shades of function in cardiovascular disease. Physiology (Bethesda) 28(6): 391-403.

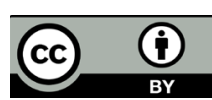

This work is licensed under Creative Commons Attribution 4.0 License DOI:10.19080/ARR.2021.06.555694
42. Janusz K, Rybakowski (2009) Matrix Metalloproteinase-9 (MMP9)-A mediating enzyme in cardiovascular disease, cancer, and neuropsychiatric disorders. Cardiovascular Psychiatry and Neurology 2009: 904836.

Your next submission with Juniper Publishers
will reach you the below assets
- Quality Editorial service
- Swift Peer Review
- Reprints availability
- E-prints Service
- Manuscript Podcast for convenient understanding
- Global attainment for your research
- Manuscript accessibility in different formats
( Pdf, E-pub, Full Text, Audio)
- Unceasing customer service
Track the below URL for one-step submission
https://juniperpublishers.com/online-submission.php

